\title{
Effect of Turmeric and Garlic to Sauropus androgynus-Bay Leaves Containing Diet on Hematological and Blood Lipids Profiles in Broiler Chickens
}

\author{
Urip Santoso*, Yosi Fenita, and Kususiyah \\ Department of Animal Husbandry, Faculty of Agriculture, University of Bengkulu \\ Jalan Raya Kandang Limun, Kota Bengkulu, Indonesia \\ *Corresponding E-mail: santoso@unib.ac.id
}

\begin{abstract}
The use of antibiotics for livestock has been banned since January 2018; therefore it is necessary to look for alternative ingredients. The addition of turmeric and garlic to Sauropus androgynus-bay leaves containing diets on hematological and lipid profiles in broilers was investigated. This study used a completely randomized design. Two hundred eighty 15-day-old female broilers were distributed into 5 treatment groups with 4 replications as follows: Control (P0); 1.25\% fermented Sauropus androgynus-bay leaves (FSBL) containing diet (P1); 1.25\% FSBL containing diet plus $1 \mathrm{~g}$ turmeric powder (P2); $1.25 \%$ FSBL containing diet plus $2 \mathrm{~g}$ garlic (P3); $1.25 \%$ FSBL containing diet plus $1 \mathrm{~g}$ turmeric and $2 \mathrm{~g}$ garlic (P4). Feeding $1.25 \%$ FSBL containing diet significantly increased the number of thrombocyte, whereas feeding the $2 \mathrm{~g}$ garlic plus $1.25 \%$ FSBL containing diet reduced white blood cell count $(\mathrm{P}<0.01)$. FSBL containing diet increased blood triglyceride $(\mathrm{P}<0.01)$. The inclusion of $1 \mathrm{~g}$ turmeric plus $2 \mathrm{~g}$ garlic to FSBL containing diet reduced triglyceride, and had the lowest mortality. The inclusion of turmetic or turmeric plus garlic to FSBL containing diet increased caecum relative weight $(\mathrm{P}<0.05)$. Sigificant findings of this research was that administration of $1 \mathrm{~g}$ turmeric and $2 \mathrm{~g}$ garlic to FSBL containing diet could be used as antitriglyceride and antimicrobial agents. It was concluded that the inclusion of $1 \mathrm{~g}$ turmeric plus $2 \mathrm{~g}$ garlic to FSBL containing diet reduced blood triglyceride. Furthermore, $1.25 \%$ FSBL containing diet increased the number of thrombocyte count, whereas $1.25 \%$ FSBL containing diet supplemented with $2 \mathrm{~g}$ garlic/kg lowered the number of white blood cells.
\end{abstract}

Keywords: Turmeric, garlic, Sauropus androgynus-bay leaves, hematological status, internal organ, lipid profiles, broiler chickens

\section{INTRODUCTION}

Indonesia has banned the use of antibiotics for livestock since January 2018 although antibiotics are needed to optimize the performance and carcass quality. Therefore, it is necessary to look for alternative ingredients that can replace antibiotics with minimal negative effects.

Medicinal plants are used to prevent various poultry diseases [1], increasing feed intake, as a coccidiostatic, anthelmintic activity [2], antimicrobial [3] and reduce coccidiosis [4] so that improve performance and reduce mortality in poultry. Thus, it is possible that medicinal plants could substitute antibiotics in poultry. In addition to the issue of prohibiting antibiotics, broiler industries are also faced with high levels of fat in the carcass. Changes in fat levels can be predicted from changes in fat concentration in the blood [5], whereas changes in poultry performance and health can be demonstrated by changes in hematologic profile and performance of internal organs.

Feeding 5\% Sauropus androgynus or 5\% bay leaves improve the hematological and blood lipid profiles in broilers [6]. In subsequent studies, the same researcher combined the use of the above leaves with lower levels. The addition of $2.5 \%$ fermented Sauropus androgynus-bay leaves reduced triglyceride, total cholesterol and LDL but raised HDL concentrations [7]with no change in hematological status.

The use of Sauropus androgynus-bay leaves at level of $2.5 \%$ resulted in a high production costs derived from diet, and therefore its use needs to be reduced. A decreased in the use of those medicinal plant mixture might reduce its effectiveness in improving hematologic profiles and blood lipids. Thus, it is necessary to add smaller amounts of other medicinal plants which could overcome those problems. The potential medicinal plants are turmeric and garlic. 
Turmeric contains mixed compounds, especially sesquiterpenes and curcumonoids as the dominant active compounds [8], polyphenols, flavonoids and ascorbic acid [9]. Turmeric supplementation in carbofuran mice increases the number of red blood cells and hemogoblin. Alagawani et al.[10]reported that the addition of turmeric lowers blood fat levels and fat peroxidation, improves immune response and increases antioxidant activity in rabbits.

Garlic powder contains saponins, tannins, alkaloids, and flavonoids [4]. Ramiah et al.[11] reported that garlic powder supplementation improved performance, feed utilization and microbiota balance in the digestive tract of broiler chickens, whereas Indrasanti et al.[4]reported that administration of garlic extract increases the number of thrombocyte in rabbits. Garlic supplementation increases the number of red blood cells, hemoglobin levels, and the number of white blood cells in mice [12\}. Sukandar et al.[13] reported that garlicturmeric supplementation improved lipid profile when compared to simvastatin in patients with lipid metabolic disorders.

Based on the above description, this research was done to analyze the effect of turmeric and garlic supplementation to fermented Sauropus androgynus plus bay leaves (FSBL) containing diets on hematologic profiles, blood lipids and the weight of the internal organs in female broiler chickens. It was hypotesized that the inclusion of turmeric and garlic to FSBL containing diets alters hematological profiles and reduces blood lipid concentration.

\section{MATERIALS AND METHODS}

\subsection{Fermentation of Sauropus androgynus and bay leaves}

Sauropus androgynus and bay leaves were fermented to decrease antinutrients [14] and crude fiber, and to increases nutritive value [14] and nutrient digestibility [15].

Fermentation was carried out using the method of Santoso et al.[16] as follows. The leaves that have been cleaned were steamed for 30 minutes. After a cold, the leaves were given $0.5 \%$ cassava yeast and then anaerobically fermented for 24 hours for Sauropus androgynus leaves and 48 hours for bay leaves. Fermented products were then dried, ground and stored in plastic bag before use.

\subsection{Animals and diets}

The experiment was conducted at Livestock Experiment Unit, Department of Animal Science, Faculty of Agriculture, Bengkulu University, Indonesia. The house, brooder ring, feeders and waterers were cleaned before arriving the chicken. Seven hundred one day broiler chickens were reared in brooders with good hygienic conditions for 14 days and were given commercial diet. Newly arrived chicks were given drinking water containing sugarto decrease stress due to travel. The temperature of the brooder was regulated according to standard maintenance procedures. At 4 and 21 days, broiler chickens were vaccinated with Newcastle Disease.

At the age of 15 days female broilers were selected, and distributed into experimental plots and given an experimental diet up to the age of 35 days. The experimental diets are presented in Table 1. Turmeric supplementation at $1 \mathrm{~g} / \mathrm{kg}$ (Saraswati et al., 2013) was able to reduce blood triglyceride and cholesterol; therefore supplementation of $1 \mathrm{~g}$ turmeric per $\mathrm{kg}$ diet was used in this research.

This study used a completely randomized design. Two hundred eighty 15-day-old female broilers were distributed into 5 treatment groups with 4 replications as follows: Control (P0); $1.25 \%$ fermented Sauropus androgynus-bay leaves (FSBL) containing $\operatorname{diet}(\mathrm{P} 1)$; $1.25 \%$ FSBL containing diet supplemented with $1 \mathrm{~g}$ turmeric powder $(\mathrm{P} 2) ; 1.25 \%$ FSBL containing diet supplemented with $2 \mathrm{~g}$ garlic (P3); $1.25 \%$ FSBL containing diet supplemented with $1 \mathrm{~g}$ of turmeric and $2 \mathrm{~g}$ garlic (P4). Broilers were maintained according to standard broiler maintenance procedures, and were given a diet and drinking water ad libitum.

\subsection{Sampling}

At 35 days of age, 4 broilers for each treatment group were drawn for blood through vena brachialis.A 1.5 $\mathrm{ml}$ blood obtained was inserted into a tubebwithout anticoagulants, centrifuged at $3000 \mathrm{rpm}$ to obtain serum. Another $1.5 \mathrm{ml}$ blood was inserted into a tube with anticoagulants for hematological profile analysis.

The microhematocrit method, and cyanmethemoglobin method were used to determine the packed cell volume (PCV), and hemoglobin, resperctively [17]. The thrombocyte count was determined using the Ress-Ecker method [18] and the white blood count (WBC) and red blood count (RBC) were determined using the hemocytometer method [17]. The blood total cholesterol, low density lipoprotein (LDL), high density lipoprotein (HDL)and triglyceride concentrations were determined by spectrophotometric method.

The results of the study were analyzed using oneway ANOVA and any significantmeanswere compared with Duncan's Multiple Range Test. The mortality rates were analyzed descriptively.

\section{RESULTS AND DISCUSSION}

\subsection{Hematological profiles}

The influence of turmeric and garlic supplementation to fermented Sauropus androgynus-bay leaves (FSBL) containing diets on the hematological profile of broiler chickens is presented in Table 1. It was shown that the inclusion of turmeric and garlic supplementation to FSBL containing diets significantly affected thrombocyte and white blood cell count $(\mathrm{P}<0.01)$, 
but the supplementation did not affect other hematologic variables. P1 had higher thrombocyte than the other treatment groups, whereas P3 had lower white blood cell count than the other treatment groups. Mortality percentage of $\mathrm{P} 0, \mathrm{P} 1, \mathrm{P} 2, \mathrm{P} 3$ and $\mathrm{P} 4$ were $2.5 \%, 2.5 \%$, $2.5 \%, 10.0 \%, 0 \%$, respectively. P4 had the lowest mortality, whereas P3 had the highest mortality.

No negative effects were observed in the medicinal plant mixture groupsas indicated by normal biochemical and hematological tests, and normal weight of vital organs. Sauropus androgunus and bayleaves contain alkaloids, tannins, steroids, saponins, phenolics and flavonoids. These compounds influence various biological processes in the body both harmfulor beneficial influences. Interestingly, there was a significant rise in thrombocyte in broiler chickens fed a $1.25 \%$ FSBL containing diet by $166.7 \%$. Santoso et al.[6]found that the inclusion of unfermented Sauropus androgynus leaf or bay leaf at 5\% increased thrombocyte count by $54.5 \%$ or $45.5 \%$. It appears that fermentation might increase an active compound in those leaves which have a role in increasing thrombocyte count. This phenomenon could beattributed to the antioxidant activity of the active compounds such as flavonoids, phenolics and saponins. Therefore, we suggest that Sauropus androgynus, bay leaf or bothmight be able to be used as a medicine to increase thrombocytes. More study is needed to isolate and to identify the active compounds of thoseleaves that are responsible for these effects.

The picture of immunity can be determined using red and white blood cell levels. Immunity of broiler chickens against various agents of disease is carried out by improving the function of immune cell systems and impairment of the immune system. This phenomenon could be determined from physiological conditions such as hematological conditions and blood biochemical values [19].Cells associated with the non-specific, innate immune response include phagocytic cells, natural killer (NK) cells, basophils, and mast cells. The primary function of a phagocytic cell is to engulf and destroy pathogens upon identification. Common phagocytes are monocyte/macrophages and neutrophils in mammals or heterophils in chickens. In recent years, researchers have shown that thrombocytes [20]are also involved in innate immunity and inflammation. The innate immune system provides an important initial response againstpathogens to limit or prevent infection.

The addition of garlic to FSBL containing diet reduced the number of white blood cells. This study is in contrary the the observation of Prasad et al.[21]who found that garlic supplementation increasedthe number of white blood cells. This shows that the compounds in garlic andSauropus androgynusplus bay leaves may interact negatively, thereby reducing the number of white blood cells. Decreasing the number of white blood cells is an indicator of decreased immune power. This can explain why there was an increase in mortality in P3.

It is interesting that the inclusion of $1 \mathrm{~g}$ turmeric plus $2 \mathrm{~g}$ garlic to FSBL containing diet had $0 \%$ mortality. Garlic contains alliin as dominant active compound, saponins, tannins, alkaloids, and flavonoids [4]. Turmeric contains mixed compounds especially sesquiterpenes and curcumonoids (especially curcumin) as the dominant active compounds [8], polyphenols, flavonoids and ascorbic acid [9].Thus, this medicinal mixture resulted in lower mortality as compared with the control group in which broiler chickens were fed a commercial feed additive containing diet.

Table 1. Effect of medicinal plant mixture on hematological status and mortality in female broiler chickens $($ mean + SD)

\begin{tabular}{|l|l|l|l|l|l|l|}
\hline \multicolumn{1}{|c|}{$\begin{array}{c}\text { Hematological } \\
\text { status }\end{array}$} & \multicolumn{1}{|c|}{ P0 } & \multicolumn{1}{|c|}{ P1 } & \multicolumn{1}{|c|}{ P2 } & P4 & P \\
\hline $\begin{array}{l}\text { Thrombocyte, } \\
\mathrm{x} 10^{3} / \mathrm{mm}^{3}\end{array}$ & $3.00 \pm 1.15^{\mathrm{a}^{*}}$ & $8.00 \pm 1.82^{\mathrm{b}}$ & $3.50 \pm 0.56^{\mathrm{a}}$ & $4.25 \pm 0.50^{\mathrm{a}}$ & $3.50 \pm 1.91^{\mathrm{a}}$ & 0.000 \\
\hline $\mathrm{Hb}, \mathrm{g} / \mathrm{dL}$ & $10.23 \pm 0.58$ & $8.89 \pm 0.99$ & $9.90 \pm 0.57$ & $9.43 \pm 0.32$ & $9.80 \pm 0.36$ & 0.079 \\
\hline $\mathrm{WBC}, \mathrm{x} 10^{3} / \mathrm{mm}^{3}$ & $287.65 \pm 2.89^{\mathrm{b}}$ & $278.88 \pm 15.14^{\mathrm{b}}$ & $281.30 \pm 11.30^{\mathrm{b}}$ & $253.31 \pm 9.32^{\mathrm{a}}$ & $284.95 \pm 4.30^{\mathrm{b}}$ & 0.002 \\
\hline $\mathrm{RBC}, \mathrm{x} 10^{6} / \mathrm{mm}^{3}$ & $2.51 \pm 0.08$ & $2.28 \pm 0.30$ & $2.44 \pm 0.16$ & $2.40 \pm 0.03$ & $3.50 \pm 0.12$ & 0.252 \\
\hline PCV, \% & $31.65 \pm 1.51$ & $28.00 \pm 3.13$ & $30.75 \pm 1.60$ & $30.18 \pm 0.18$ & $30.69 \pm 0.82$ & 0.075 \\
\hline $\mathrm{MCV}, \mathrm{fL}$ & $126.30 \pm 2.68$ & $123.05 \pm 2.78$ & $126.13 \pm 3.02$ & $124.88 \pm 2.71$ & $126.75 \pm 1.30$ & 0.787 \\
\hline MCH, pg & $40.78 \pm 1.60$ & $39.45 \pm 1.27$ & $40.63 \pm 1.04$ & $40.84 \pm 0.83$ & $41.63 \pm 0.41$ & 0.428 \\
\hline MCHC, g/dL & $32.30 \pm 0.78$ & $32.08 \pm 0.72$ & $32.18 \pm 0.39$ & $32.25 \pm 0.33$ & $32.58 \pm 0.13$ & 0.557 \\
\hline Mortality, \% & 2.5 & 2.5 & 2.5 & 10.0 & & 0 \\
\hline
\end{tabular}




\subsection{Internal organ weights}

The effect of turmeric and garlic supplementation to FSBL containing diets on internal organ weight and the toxicity score is presented in Table 2. It was shown that the inclusion of turmeric and garlic supplementation to FSBL containing diets had no effect on the relative weights of liver, heart, spleen, intestine, proventriculus, gall bladder and gizzard, but it influenced relative caecum weight $(\mathrm{P}<0.05)$. $\mathrm{P} 0$ had lower caecum weight than $\mathrm{P} 2$ and P4. P2 and P4 had a higher caecum weight at $56.5 \%$ and $39.1 \%$, respectively as compared with the P0. The treatments did not influence toxicity score. No change in internal organ weihts indicate that medicinal plant mixute supplementation did not negatively

$\mathrm{P} 0=$ Control without medicinal plant mixture; $\mathrm{P} 1$ $=$ Feeds with medicinal plant mixture [composed with $1.25 \%$ fermented Sauropus androgynus-bay leaves $($ FSBL) $] ; \quad$ P2 = Feed with medicinal plant mixture (composed with FSBL plus $1 \mathrm{~g}$ turmeric powder; P3 = Feedwith medicinal plant mixture (composed with FSBL plus $2 \mathrm{~g}$ garlic); $\mathrm{P} 4=$ Feed with medicinal plant mixture (composed with FSBL plus $1 \mathrm{~g}$ of turmeric and $2 \mathrm{~g}$ garlic). *The supercripts show significantly diffrent at $\mathrm{P}<0.05$ impair the function of internal organs. The present study proved that inclusion of medicinal plant mixture did not cause toxicity as indicated by no significant change in toxicyty score.Thus, medicinal plant mixture formulated in the present study could be given to broilers as a substitute of top mix (commercial feed additives).However, it is suggested to carry out further studies, feeding different doses for a long period to determine the possible toxicity of medicinal plant mixture composed bySauropus androgynus, bay leaf, turmeric and garlic mixture.

The caeca are a site of water soluble non-starch polysacharide degradation [22]. Caeca weight was negatively correlated with water losses [23], which confirm that caeca function as water absorption [24]. In caeca, salts and water are reabsorbed, and uric acid and carbohydrates are fermented by the microflora to ammonia and VFAs. It is postulated that heavier caeca would increase fermentation by microflora in caeca, and increase water and nutrient absorption. Higher caeca weight is positively correlated with increased nutrient digestibility, total digestible nutrients, digestible protein, and nutrient utilization [25]. It is suspected that there is an increase in digestive material entering the caeca and an increase in fermentation of nutrients by the microflora in the caeca.

\subsection{Blood lipid profiles}

Table 3 shows the effect of turmeric and garlic supplementation to FSBL containing diets on blood lipid profiles. It was shown that the inclusion of the turmeric and garlic supplementation to FSBL containing diets significantly influenced blood triglyceride $(\mathrm{P}<0.01)$, but it had no effect on blood cholesterol, LDL and HDL. P4 had lower triglyceride than $\mathrm{P} 0$, whereas $\mathrm{P} 1$ had the highest. Blood triglyceride of $\mathrm{P} 4$ was reduced by $54.5 \%$, whereas blood triglyceride of P1 was increased by $68.4 \%$ as compared with P0.

Table 2. Effect of medicinal plant mixture on relative internal organ weihgt of female broiler chickens (mean \pm SD)

\begin{tabular}{|l|l|l|l|l|l|l|}
\hline Internal Organ & $\mathrm{P} 0$ & $\mathrm{P} 1$ & $\mathrm{P} 2$ & $\mathrm{P} 3$ & $\mathrm{P} 4$ & $\mathrm{P}$ \\
\hline Liver, \% & $2.12 \pm 0.15$ & $2.07 \pm 0.05$ & $1.99 \pm 0.11$ & $2.08 \pm 0.15$ & $2.05 \pm 0.22$ & 0.292 \\
\hline Spleen, \% & $0.10 \pm 0.03$ & $0.12 \pm 0.02$ & $0.09 \pm 0.04$ & $0.09 \pm 0.01$ & $0.10 \pm 0.02$ & 0.557 \\
\hline Proventriculus, \% & $0.35 \pm 0.04$ & $0.41 \pm 0.04$ & $0.35 \pm 0.04$ & $0.39 \pm 0.04$ & $0.43 \pm 0.05$ & 0.150 \\
\hline Gizzard, \% & $1.68 \pm 0.18$ & $2.28 \pm 0.14$ & $1.60 \pm 0.21$ & $1.76 \pm 0.16$ & $1.78 \pm 0.14$ & 0.111 \\
\hline Heart, \% & $0.27 \pm 0.01$ & $0.26 \pm 0.01$ & $0.27 \pm 0.03$ & $0.27 \pm 0.03$ & $0.28 \pm 0.01$ & 0.876 \\
\hline Caecum, \% & $0.46 \pm 0.03^{\mathrm{a}}$ & $0.57 \pm 0.07^{\mathrm{ab}}$ & $0.72 \pm 0.18^{\mathrm{b}}$ & $0.62 \pm 0.08^{\mathrm{ab}}$ & $0.64 \pm 0.06^{\mathrm{b}}$ & 0.028 \\
\hline Intestine, \% & $2.75 \pm 0.31$ & $2.94 \pm 0.35$ & $3.03 \pm 0.22$ & $3.16 \pm 0.02$ & $3.12 \pm 0.26$ & 0.269 \\
\hline $\begin{array}{l}\text { Intestine length, } \\
\text { cm/100 g BW }\end{array}$ & $15.13 \pm 1.14$ & $14.99 \pm 2.49$ & $15.24 \pm 1.70$ & $15.40 \pm 0.22$ & $15.47 \pm 1.91$ & 0.998 \\
\hline Gall bladder & $0.096 \pm 0.014$ & $0.101 \pm 0.012$ & $0.094 \pm 0.002$ & $0.103 \pm 0.015$ & $0.086 \pm 0.008$ & 0.487 \\
\hline Toxicity, \% & $2.22 \pm 0.18$ & $1.19 \pm 0.06$ & $2.08 \pm 0.12$ & $2.17 \pm 0.15$ & $2.15 \pm 0.22$ & 0.238 \\
\hline
\end{tabular}

P0 = Control without medicinal plant mixture; P1 = Feeds with medicinal plant mixture [composed with $1.25 \%$ fermented Sauropusandrogynus-bay leaves (FSBL)]; P2 = Feed with medicinal plant mixture (composed with FSBL plus $1 \mathrm{~g}$ turmeric powder; P3 = Feed with medicinal plant mixture (composed with FSBL plus $2 \mathrm{~g}$ garlic); P4 = Feed with medicinal plant mixture (composed with FSBL plus1 $\mathrm{g}$ of turmeric and $2 \mathrm{~g}$ garlic). 
Table 3. Effect of medicinal plant mixture on blood lipid profiles of female broiler chickens (mean+SD)

\begin{tabular}{|l|l|l|l|l|l|l|}
\hline Lipid, mg/dL & P0 & P1 & P2 & P3 & P4 & P \\
\hline Triglyceride & $78.00 \pm 20.50^{\mathrm{b}}$ & $131.88 \pm 35.00^{\mathrm{c}}$ & $67.88 \pm 29.73^{\mathrm{ab}}$ & $72.06 \pm 8.33^{\mathrm{ab}}$ & $35.50 \pm 9.47^{\mathrm{a}}$ & 0.000 \\
\hline Cholesterol & $107.00 \pm 22.23$ & $102.25 \pm 18.68$ & $116.00 \pm 8.08$ & $106.25 \pm 22.54$ & $103.75 \pm 10.90$ & 0.653 \\
\hline HDL & $74.00 \pm 14.73$ & $64.66 \pm 16.83$ & $83.75 \pm 11.18$ & $70.75 \pm 15.72$ & $80.75 \pm 10.40$ & 0.135 \\
\hline LDL & $20.00 \pm 8.52$ & $20.50 \pm 18.68$ & $31.00 \pm 9.64$ & $29.25 \pm 13.72$ & $20.50 \pm 4.73$ & 0.112 \\
\hline
\end{tabular}

P0 = Control without medicinal plant mixture; P1 = Feeds with medicinal plant mixture [composed with $1.25 \%$ fermented Sauropus androgynus-bay leaves (FSBL)]; P2 = Feed with medicinal plant mixture (composed with FSBL plus $1 \mathrm{~g}$ turmeric powder; P3 = Feed with medicinal plant mixture (composed with FSBL plus 2 g garlic); P4 = Feed with medicinal plant mixture (composed with FSBL plus $1 \mathrm{~g}$ of turmeric and $2 \mathrm{~g}$ garlic). *The supercripts show significantly diffrent at $\mathrm{P}<0.05$.

Santoso et al.[7] found that the inclusion of FSBL at $2.5 \%$ reduced blood triglyceride. However, lower FSBL inclusion applied in the present study was not adequate to lower blood triglyceride. The inclusion of $1 \mathrm{~g}$ turmeric powder or $2 \%$ garlic powder to FSBL containing diet did not decrease triglyceride because of the low dose of garlic and turmeric. The inclusion of $1 \mathrm{~g}$ turmeric powder or $2 \%$ garlic powder to FSBL containing diet did not decrease triglyceride because of the low dose of garlic and turmeric.

This shows that the dose of turmeric and garlic in this study is still too low. Feeding $1.5 \%$ garlic reduced blood triglyceride concentration [26]. Daneshyar et al. [27] reported that feeding $0.5 \%$ turmeric powder decreasedblood triglyceride concentration of broiler chickens.

There was a decrease in blood triglyceride when $1 \mathrm{~g}$ turmeric and $2 \mathrm{~g}$ garlic was added to FSBL containing diet (P4). Curcumin as dominant compound in turmeric and allicin as dominant compound in garlic are thought to be synergistically able to reduce triglycerides. In addition, other compounds such as tannin, saponins, phenolics and flavonoids might also contribute to the reduction of triglyceride.

Garlic stimulates lipolysisand inhibits lipogenesis in adipocytes[28]. Significant downregulation of the PPAR $\gamma$, ACC, aP2 and GPDH genes were observed in garlic supplemented group [29].Curcumin, a major active component of turmeric suppressed the expression of lipogenic enzymes such as ATP citrate lyase, Acetyl-CoA carboxylase and Fatty acid synthase [30] and resulting in the reduction of fatty acid synthesis.

Santoso et al.[7] found that the inclusion of FSBL at $2.5 \%$ reduced blood cholesterol. Thus, the addition of $1.25 \%$ FSBL in the present study was unadequate for reducing blood cholesterol. The inclusion of garlic, turmeric or both to FSBL diet did not decrease blood cholesterol. The present study was in contrary with several investigators who reported that $1 \mathrm{~g} / \mathrm{kg}$ turmeric [31], or $2 \mathrm{~g} / \mathrm{kg}$ garlic [32, 33]did not result in a decrease total cholesterol concentration.

\section{CONCLUSION}

It was concluded that the inclusion of $1 \mathrm{~g}$ turmeric plus $2 \mathrm{~g}$ garlic to FSBL containing diet decreased blood triglyceride. In addition, 1.25\% FSBL containing diet increased thrombocyte count, whereas $1.25 \%$ FSBL containing diet supplemented with $2 \mathrm{~g}$ garlic/ $\mathrm{kg}$ decreased the number of white blood cells. Sigificant finding of this research was that administration of $1 \mathrm{~g}$ turmeric and $2 \mathrm{~g}$ garlic to FSBL containing diet could be used as antitriglyceride and antimicrobial agents.

\section{ACKNOWLEDGMENT}

The authors thank the Director General of Higher Education, the Ministry of Research, Technology and Higher Education, Indonesia under contract number769/UN30.15/LT/2019. The authors are also grateful to Kiki Rusdi,Elsa Marta Saitri, Ander Agustian, and Novriska WinniSimanjutak for assistingin the conduct of this research.

\section{REFERENCES}

[1] Dhama, K., S. K. Latheef, S. Mani, H. A. Samad, K. Karthik, R. Tiwari, Rifat U. Khan, M. Alagawany, M. R. Farag, G. M. Alam, V. Laudadio, \& V. Tufarelli, 'Multiple beneficial applications and modes of action of herbs in poultry health and production-A review', Int. J. Pharmacol, vol. 11, pp. 152-176, 2015.

[2] Aggarwal, R., K. Kaur, M. Suri, \& U. Bagai, 'Anthelmintic potential of Calotropis procera, Azadirachta indica and Punica granatum against Gastrothylax indicus, J Parasit Dis, vol. 40 no. 4, pp. 1230-1238, 2016.

[3] Duraiswamy, H., S. Nallaiyan, J. Nelson, P.R. Samy, M. Johnson, \& I. Varaprasadam, 'The effect of extracts of Selaginella involvens and Selaginella inaequalifolialeaves on poultry pathogens', Asian Pacific J. Trop. Med, vol. 3, pp. 678-681, 2010.

[4] Indrasanti, D., M. Indradji, S, Hastuti, E. Aprilliyanti, Fatikha, \& K.A. Rosyadi, 'The administration of garlic extract onEimeria stiedaioocysts and the 
hematological profile of the coccidia infected rabbits', Med. Pet, vol. 40, no. 3, pp. 158-164, 2017.

[5] Shim, K. S., G. H. Park, C. J. Choi, \& C. S. Na, 'Decreased triglyceride and cholesterol levels in serum, liver and breast muscle in broiler by supplementation of dietary Codonopsis lanceolata root', Asian-Australas. J. Anim. Sci, vol. 17, no. 4, pp. 511-513, 2004.

[6] Santoso, U., Y. Fenita, \& Kususiyah, 'The Effect of medicinal herb inclusion on hematologic status andblood lipid profiles in broiler chickens', Int. J. Poultry Sci, vol. 16, no. 10, pp. 415-423, 2017.

[7] Santoso, U., Y. Fenita, \& Kususiyah, 'The effect of fermented Sauropus androgynus plus bay leaf inclusion on the hematologic and lipid profiles of female broiler chickens', Int. J. Poultry Sci, vol. 17, no. 9, pp. 410-417, 2018.

[8] Lateef, E. A., F. Mahmoud, O. Hammam, E. ElAhwany, E. El-Wakil, S. Kandil, H. A. Taleb, M. ElSayed, \& H. Hassenein, 'Bioactive chemical constituents of Curcuma longa L. rhizomes extract inhibit the growth of human hepatoma cell line (HepG2)', Acta Pharm, vol. 66, pp. 387-398, 2016.

[9] Hossen, Md.S., E.M. Tanvir, M.B. Prince, S. Paul, M. Saha, Md.Y. Ali, S.H. Gan, Md.I. Khalil, \& N. Karim, 'Protictive mechanism of turmeric (Curcuma longa) on carboburan-induced hematological and hepatic toxicities in a rat model. Pharma', Biol, vol. 55, no. 1, pp. 1937-1945, 2017.

[10] Alagawani, M., E. A. Ashour, \& F.M. Reda, 'Effect of dietary supplementation of garlic (Allium sativum) and turmeric (Curcunga longa) on growth performance, carcass traits, blood profile and oxidative status in growing rabbit', Ann. Anim. Sci, vol. 16, no. 2, pp. 489-505, 2016.

[11] Ramiah, S. K., I. Zulkifli, \& N. A. B. Rahim, 'Effects of two herbal extracts and virginiamycin supplementation on growth performance, intestinal microflora population and fatty acid composition in broiler chickens', Asian-Australas. J. Anim. Sci, vol. 27, no. 3, pp. 375-382, 2014.

[12] Tikare, S. N., S. Yendigeri, A. D. Gupta, S. A. Dhundasi, \& K. K. Das, 'Effect of garlic (Allium sativum) on hematology and erythrocyte antioxidant defense system of albino rats exposed to heavy metals (nickel II \& chromium VI)', Indian J. Physiol. Pharmacol, vol. 56, no. 2, pp. 137-146, 2012.

[13] Sukandar, E. Y., P. Sudjana, J. I. Sigit, N. P. E. Liliqia, \& F. Lestari, 'Safety of garlic (Allium sativum) and turmeric (Curcuma domestica) ekstract in comparison with simvastatin on improving lipid profile in dyslipidemia patients', J. Med. Sci, vol. 13, no. 1, pp. 10-18, 2013

[14] Cui, L., D. J. Li, \& C. Q Liu, 'Effect of fermentation on the nutritive value of maize', Int. J. Food Sci. TechnoL, vol. 47, pp. 755-760, 2012.

[15] Salem, A. Z. M., H. Alsersy, L. M. Camacho, M. M. El-Adawy, M. M. Y. Elghandour, A. E. Kholif, N. Rivero, M. U. Alonso, \& A. Zaragoza, 'Feed intake, nutrient digestibility, nitrogen utilization, and ruminal fermentation activities in sheep fed Atriplex halimus ensiled with three developed enzyme cocktail', Czech J. Anim. Sci, vol. 60, pp. 185-194, 2015.

[16] Santoso, U., Y. Fenita, Kususiyah,\& I.G.N.G. Bidura, 'Effect of fermented Sauropus androgynus leaves on meat composition,amino acid and fatty acid compositions in broiler chickens', Pak. J. Nutr, vol. 14, pp. 799-807, 2015.

[17] Coles, E. H, Veterinary Clinical Pathology. $4^{\text {th }}$ ed. W.B. Saunders Co., Philadelphia, 1986.

[18] Brown, B. A, 'Direct methods for platelet counts, rees and ecker method. In: Hematology: Principles and Procedures, Brown, B.A. (Ed.). $2^{\text {nd }}$ ed. Lea $\&$ Febiger, Philadelphia, 1976.

[19] Toghyani, M., M. Tohidi, A. A. Gheisari, \& S. A. Tabeidian, 'Performance, immunity, serum biochemical and hematological parameters in broiler chicks fed dietary thyme as alternative for an antibiotic growth promoter', Afr. J. Biotechnol. Vol. 9, pp. 6819 $6825,2010$.

[20] Paul, M., S. Paolucci, N. Barjesteh, R. D. Wood, K. A. Schat, \& S. Sharif, Characterization of chicken thrombocyte responses to Toll-Like receptor ligands. PLOS One vol. 7, no. 8, e43381, 2012.

[21] Prasad, R., M. K. Rose, M. Virmani, S. L. Garg, \& J. P. Puri, 'Effect of garlic (Allium sativum) suppelentation on haematological parameters in chicken (Gallus domesticus)', Indian J. Anim. Res, vol. 43, no. 3, pp. 157-162, 2009.

[22] Svihus, B., M. Choct, \& H. L. Classen, 'Function and nutritional roles of theavian caeca: a review', World's Poultry Sci. J, vol. 69, pp. 249-264, 2013.

[23] Maisonnier, S., J. Gomez, A. M. Chagneau, \& B. Carre, 'Analysis of variability in nutrient digestibilities in broiler chickens', Bri. Poultry Sci, vol. 42, pp. 7076, 2001.

[24] McNab, J. M, 'The avian caeca: A review', World Poultry Sci. J, vol. 29, pp. 251-263, 1973.

[25] Abu-Hafsa, S. H., A. Z. M. Salem, A. A. Hassan, A. E. Kholif, M. M. Y. Elghandour, A. Barbabosa, \& S. Lopez, 'Digestion, growth performance and caecal fermentation in growing rabbits fed diets containing foliage of browse trees', World Rabbit Sci, vol. 24, pp. 263-293, 2016.

[26] Prasad, R., M. K. Rose, M. Virmani, S. L. Garg, \& J. P. Puri, 'Lipid profile of chicken (Gallus domesticus) in response to dietary supplementation of garlic (Allium sativum)', Int. J. Poultry Sci, vol. 8, no. 3, pp. 270-276, 2009.

[27] Daneshyar, M., M. Alizadeh Ghandkanlo, F. Sabzi Bayeghra, F. Farhangpajhoh, \& M. Aghaei, 'Effects of dietary turmeric supplementation on plasma lipoproteins, meat quality and fatty acid composition in broilers', South African J. Anim. Sci vol. 41, no. 4, pp. 420-428, 2011.

[28] Nam, H., H. Jung, Y. Kim, B. Kim, K. H. Kim, S. J. Park, \& J. G. Suh, 'Aged black garlic extract regulates lipid metabolism by inhibiting lipogenesis and promoting lipolysis in mature 3T3-L1 adipocytes', 
Food Sci. Biotechnol, vol. 27, no. 2, pp. 575-579, 2018.

[29] Kim, M.J. \& H.K. Kim, 'Effect of garlic on high fat induced obesity', Acta Biologica Hungarica vol. 62, no. 3, pp. 244-254, 2011.

[30] Maithilikarpagaselvi, N., M. G. Sridhar, R. P. Swaminathan, R. Sripradha, \& B. Badhe, 'Curcumin inhibits hyperlipidemia and hepatic fat accumulation in high-fructose-fedmale Wistar rats', Pharma. Biol, vol. 54, no. 12, pp. 2857-2863, 2016.

[31] Saraswati, T. R., W. Manalu, D. R. Ekastuti, \& N. Kusumorini, 'The role of turmeric powder in lipid metabolism and its effect on quality of the first quail's egg', J. Indonesian Trop. Anim. Agric, vol. 38, no. 2, pp. 123-130, 2013.

[32] Samanthi, K. A. M., W. A. D. Nayananjalie, A. M. J. B. Adikari, \& R. Liyanage, 'Dietary garlic (Allium sativum L.) supplementation on performance, meatquality and lipid profile in broilers', Rajarata University J, vol. 3, pp. 17-24, 2015.

[33] Jimoh A. A., B. R. Olorede, A. Abubakar, J. P. Fabiyi, E. B. Ibitoye, N. Suleiman, \& S. Garba, 'Lipids profile and haematological indices of broiler chickens fed garlic (Allium sativum) - supplemented diets', $J$. Vet. $A d v$, vol. 2, no. 10, pp. 474-480, 2012. 